\title{
Remediation of small scale uranium mining activities in the South Alligator Valley, Kakadu National Park
}

\author{
T.R. Reszat O'Kane Consultants Pty Ltd, Australia \\ G. Balding Parks Australia, Department of the Environment, Water, Heritage and the Arts, Australia \\ M. Fawcett Fawcett Mine Rehabilitation Services Pty Ltd, Australia
}

\begin{abstract}
The director of National Parks has initiated works to remediate, over four years, 13 abandoned uranium mines and related sites in the Gunlom Aboriginal Land Trust (GLT) area located in the upper South Alligator River Valley of Kakadu National Park. There are two categories of abandoned uranium mines and related sites in the GLT area: namely, non-radiologically contaminated sites (termed Part A sites); and sites containing residual quantities of tailings and run-of-mine wastes with low levels of radiological contamination (termed Part B sites).

The portion of the works discussed in this paper involves characterisation of the Part B sites and the design of an engineered containment facility suitable for low level radiologically contaminated materials. Site remediation and engineered containment design involved a comprehensive and critical assessment of both the waste sites and the containment area. Sites investigated and characterised included Battery Bund, El Sherana Mine, El Sherana Village, Palette Mine, tailings residues near Rockhole Creek, South Alligator Village and Weighbridge.
\end{abstract}

Physical, geochemical and radiological material characterisation of waste was undertaken to assess which materials are at risk and require additional works to supplement previous remediation. Radiological assessment included gamma measurements and radiometric laboratory analyses. Geochemical assessment involved sampling and characterisation based on in-field gamma measurements and sampling of known waste materials from a non-radiological perspective. Geochemical characterisation of samples involved solids and leach extraction chemistry, and testing to assess acid rock drainage (ARD) potential. Laboratory geochemical and radiological results were assessed through geochemical modelling to predict pore-water speciation of all wastes and the likelihood of solute migration.

Containment site assessment involved geochemical and radiological characterisation to obtain base-line conditions and considered geochemical mixing and speciation modelling to predict the effects of containment leachate on-site base-line chemistry, should migration of solutes occur. The containment was designed using industry best practice using site-specific physical characteristics to develop the optimum design option, and considered geotechnical, hydrological, erosional and geochemical processes. Design alternatives were considered using soil-atmosphere, seepage and regional groundwater modelling including full sensitivity analyses to ensure proper design specifications were met.

The preferred design alternative includes a robust cover system to limit net percolation of water into the waste and consists of a thick growth medium underlain by a compacted clay layer (CCL). The containment is located in the vadose zone, $5 \mathrm{~m}$ above maximum groundwater levels, in low permeability, clay-rich materials, and includes a secondary containment method consisting of a CCL at the base of the waste. The design includes automated instrumentation for monitoring and surveillance including: soil suction, temperature, and moisture sensors throughout the profile; provision of radon gas egress monitoring though the cover system; vibrating wire piezometers and lysimeters at the base to assess seepage and pore-water pressures; cover erosion and runoff measurements; piezometers appropriately sited to intercept potential seepage and monitor hydraulic heads through the containment area; and meteorological instrumentation. 


\section{Introduction}

Exploration and discovery of the South Alligator River Valley uranium field in the Gimbat pastoral lease began in 1953. More than 50 radiological anomalies were identified in the upper South Alligator River Valley, with 13 of these anomalies being developed into mines between 1956 and 1964. The location of several of the mines close to El Sherana is presented in Figure 1. Individual mines and supporting infrastructure were small in scale, and the overall production from the mines was approximately $875 \mathrm{t}$ of $\mathrm{U}_{3} \mathrm{O}_{8}$. The area was originally serviced by two mining villages; namely, South Alligator Village serving the Rockhole Mine and El Sherana Village serving the southern mines. At the end of the mining operations the sites were abandoned without any attempt at remediation. Mineral exploration continued in the area and in the 1980s there was a focus on the mine sites of Palette, El Sherana and Coronation Hill (Guratba), focussing on gold, platinum and palladium, which appeared to be located in halos of mineralisation around the former uranium mineralised areas (Waggitt, 2004). In 1985-1986, Pacific Gold Mines NL removed most of the tailings material within the Rockhole Mine area for off-site reprocessing to extract gold (Pfitzner and Martin, 2003).

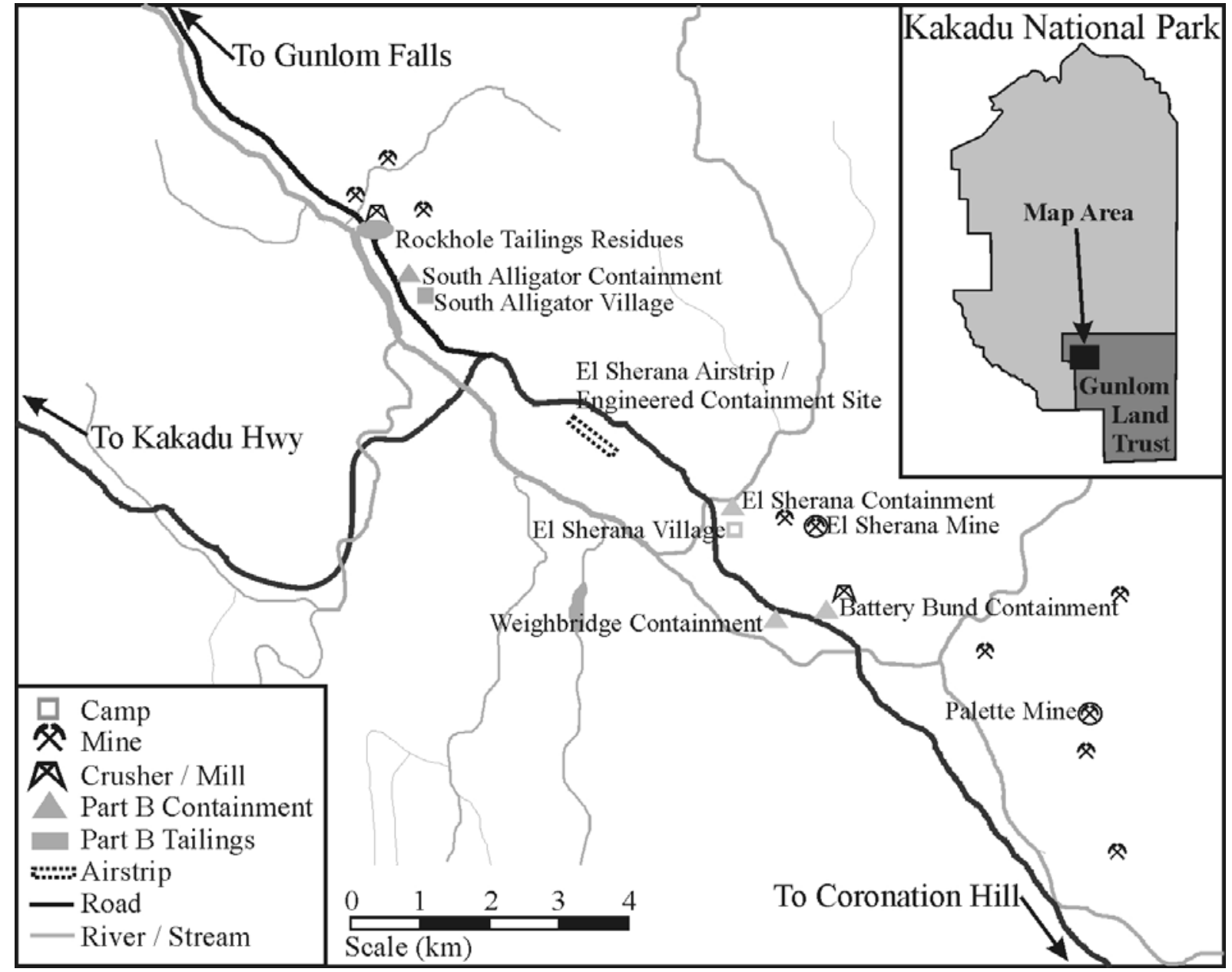

Figure 1 Location of old mining, exploration and Part B sites. Also shown is the location of the engineered containment facility at the EI Sherana airstrip. Sites shown with labels are those involved in the current works

Discussions regarding the rehabilitation of the area began in the late 1970s due to the importance of traditional Aboriginal owners (TOs) consultation being established in 1976, with the Aboriginal Land Rights Act, Kakadu National Park being created in 1979 in areas to the north, with an intention to include the South Alligator River Valley at a later date, and abandoned mines causing concerns regarding environmental issues. 
These issues led the Federal Government to decide to undertake a hazard reduction programme in the area. Parks Australia is the agency with the responsibility of delivering a rehabilitation programme under the lease agreement of the South Alligator River Valley between Kakadu National Park and the TOs (Waggitt, 2004). The construction of a containment facility and relocation of materials to the containment facility is an intervention, the key aim of the intervention is to substantially improve the existing situation (ARPANSA, 2002).

\subsection{Traditional owner consultation and protection of the cultural and ecological valued area}

Kakadu National Park is nationally (Register of the National Estate) and internationally (World Heritage List) recognised for its cultural and natural values and is classified as a category II area (national park) under the World Conservation Union (IUCN) classification scheme of protected areas. Aboriginal people have lived in the area covered by Kakadu National Park continuously for at least 50,000 years. The area of interest, the GLT area is a focal part of a cultural landscape dominated by a region known as Sickness Country, a notional boundary, within which is a cultural landscape rich in a diversity of sacred sites, rock art sites, ceremonial sites, burial sites, stone arrangements, camp sites and archaeological sites (Stockton et al., 2003; Press and Lawrence, 1995). The GLT is the sub-group of the Jawoyn Nation that represents the specific traditional Aboriginal landowners and custodians for the lands within which the project is located. In 1996 the GLT was successful in its land claim over the former Gimbat pastoral lease, and leased the area back to the director of National Parks for continuing use as a part of Kakadu National Park. A clause in the lease required that the authorities "develop and implement a plan of rehabilitation to limit and, where possible, reverse the impact on the environment of all former mining activities" by the end of 2015 (National Parks, 2007).

In contrast to the era during which mining took place, TOs have been able to exercise their decision making rights and processes throughout the development of the rehabilitation planning. Over the years of the consultation process the members of the consultative committee have developed a great deal of mutual trust and respect, primarily because of the way everyone has worked together constructively to maintain a process that is transparent, relevant and useful to all parties concerned. The TOs consider they are responsible for the management and well being of the land and those people using it, and they have a system of community decision making that is built around consensus rather than the western notion of democratic majority rule. The time scale for decision making for TOs thus often seems a lot longer than westerners might be accustomed to, hence patience and understanding are essential elements of such cross-cultural situations. All parties involved were confronted with the complex task of developing appropriate actions to redress the impacts of past uranium mining activity on the sacrosanct zone of Sickness Country, all situated within a famous National Park of World Heritage status (Stockton et al., 2003). The process involved the input of expert knowledge from diverse fields and sources to cover cultural/anthropological knowledge, radiological science, environmental science, mining and engineering, and park administration. The result that is being achieved is a combination of science and technology (providing a trade-off between dose, risk, legal compliance, and the long-term stability of containments) and traditional beliefs and values (minimising disturbance to country, protection of sacred sites and ceremonial places, meeting social concerns and observation of tradition). The system for achieving this outcome, possibly unique, has been developed over time and stands as an example of cross-cultural cooperation that all parties can be justifiably proud of (Stockton et al., 2003).

\subsection{Rehabilitation history}

A programme aimed at reducing both radiological and physical hazards was undertaken in 1990 and 1991. This programme resulted in infilling and sealing-off of mine shafts and adits with grates, and burial of radioactive waste material and mine plant in containments. These interim containments have since been monitored regularly for above ground radiation by the Office of the Supervising Scientist (OSS) (Pfitzner and Martin, 2003; Waggitt, 2003). A number of studies were initiated in 2003 as part of the rehabilitation plans for the South Alligator River Valley. These included a desk top review to determine sites suitable for construction of a new containment, focussing on suitable sites under the remediation criteria as agreed with the Australian Radiation and Nuclear Safety Agency (ARPANSA), and assessed the advantages and 
disadvantages of siting the containment outside the GLT Area but within the Northern Territory. This assessment favoured siting the containment facility within the GLT Area (EWL and FMRS, 2003). A number of piezometers were installed at two potential sites, i.e. the El Sherana airstrip and South Alligator Village, to test the hydrologic criteria for suitable facility siting. From this work it was determined that only the El Sherana airstrip site met the hydrologic criteria required (EWL, 2007). A preliminary environmental assessment was undertaken at the El Sherana airstrip which included flora and fauna surveys, and a preliminary assessment of the airstrip area landform (specifically erosional characteristics). The airstrip was found to be suitable under these criteria $(\mathrm{EcOz}, 2007)$. Additional piezometers were installed to further delineate the hydrological conditions at the airstrip (FMRS, 2007). In 2007, O'Kane Consultants was awarded the tender to characterise the wastes at the Part B Sites (sites with unresolved rehabilitation issues involving radiologically contaminated material), characterise the airstrip materials and design a containment facility at the airstrip.

\section{$2 \quad$ Part B sites}

The Part B Sites are comprised of interim containments, a tailings residue site, and two mine sites (Figure 1). The interim containments are Battery Bund, El Sherana Village, South Alligator Village, and Weighbridge. The tailings residue site is located nearby at Rockhole Creek and the two mine waste sites are El Sherana and Palette. From the materials characterisation programme the total remedial volume is approximately $16,500 \mathrm{~m}^{3}$ of low grade radiologically contaminated material. Each Part B site (excluding the mine sites) was excavated to delineate the extent of the containment (length, width and depth), and to obtain representative samples for geochemical and radiological characterisation.

\section{Material characterisation}

Geochemical analyses consisted of paste $\mathrm{pH}$ and conductivity, solids digests, leach extractions, radiometric analysis and ARD potential. For groundwaters, analysis consisted of redox (Eh), pH, conductivity, cation and anions, and full metals scan.

Geotechnical material characterisation included field observations, particle size distributions, Atterberg limits, specific gravity, compaction testing (standard and modified proctor), dispersive testing, crumb tests, double hydrometer, pinhole, triaxial permeability, and in situ full-scale field compaction trials.

Radiometric analyses included laboratory analysis for Ra-226, Ra-228 and $\mathrm{Pb}-210$, and total uranium concentrations, and leach extraction uranium concentrations. Aside from the laboratory testing, extensive field measurements using a gamma probe were taken at the Rockhole tailings residue site to delineate the areas of contamination.

\subsection{Waste materials characterisation}

\subsubsection{Geochemistry}

The average waste chemistry was determined by chemical speciation modelling using the program Phreeqc (Parkhurst and Appelo, 1999). This program requires the use of a user specified thermodynamic database to calculate aqueous and mineral equilibrium. For the purposes of this work, a database constructed by the Lawrence Livermore National Laboratories (LLNL) was utilised (Johnson, 1992). This database provides a wide range of species and was developed for use in the nuclear waste disposal industry. The database was modified to include equilibrium reactions for a number of species pertinent to the study not included within the LLNL data namely that for radium (Hummel et al., 2002). The modelling of each sample utilised solids leach extraction solution results, which were recalculated from a 1:3 soil to water dilution to actual porewater conditions. Results from each averaged site were then mixed using a weighting factor, which considered the volume contribution of each site to the containment volume. Chemical results were compared to Australian and New Zealand Environment and Conservation Council and National Health and Medical Research Council guidelines for drinking water, livestock and aquatic guidelines (ANZECC, 2000; NHMRC, 2004). There are no current or anticipated users of groundwater in the area, however, a comparison is included as it provides a means of water quality comparison. The ANZECC aquatic guidelines were used to 
determine acceptable concentration for potential seepage into the South Alligator River using a regional groundwater model.

The containment waste averaged $\mathrm{pH}$ was predicted to be 6.8 (neutral) with slightly reducing conditions. As the waste is not predicted to be fully saturated, it is anticipated that in situ oxidising conditions will remain. The wastes range from being $\mathrm{NaSO}_{4}$ to $\mathrm{NaCl}$ dominated waters, with very low alkalinity present. Concentrations of solutes are generally below or slightly higher than ANZECC/NHMRC guidelines with the exception of several elements as shown in Table 1. These included Ra-226, aluminium, uranium, and iron.

It should be noted that the aqueous concentrations of Ra-226 was determined from the solids radium concentrations assuming solubility comparable to barium, which has very similar properties. In terms of comparison to ANZECC and NHMRC guidelines it should be noted that water from the area has long been considered unsuitable for human consumption and guidelines are only applicable when considering the possibility of solute transport to the South Alligator River.

Table 1 Summary of waste source term averages compared to various ANZECC guidelines

\begin{tabular}{llll}
\hline Element & Concentration & ANZECC/NMHRC & Reference \\
\hline Radium $(\mathrm{Bq} / \mathrm{l})$ & 77 & 5 & Livestock drinking water \\
Aluminium $(\mathrm{mg} / \mathrm{l})$ & 8.1 & 5 & Livestock drinking water \\
Uranium $(\mathrm{mg} / \mathrm{l})$ & 0.13 & $0.2(0.02)$ & Livestock drinking water (drinking water) \\
Iron $(\mathrm{mg} / \mathrm{l})$ & 15 & 0.3 & Drinking water (aesthetic) \\
\hline
\end{tabular}

\subsubsection{Radiometric characterisation}

The average solids laboratory results for the materials at each Part B site are presented in Table 2. The containment average was determined from a volume contribution from each site in the containment. The site characterisation at the Rockhole tailings residues included 58 test pits to delineate which areas that required remediation both laterally and with depth. Measurements were taken at the surface and at $500 \mathrm{~mm}$ increments with depth. Gamma concentrations measured throughout the profile identified several areas that require remediation to a minimal depth. Figure 2 shows the approximate extent of surface remedial activities at Rockhole site.

Table 2 Summary of the average radiochemistry results from the Part B sites and a containment 'average'

\begin{tabular}{lllll}
\hline Site & $\begin{array}{l}\mathbf{R a - 2 2 6} \\
\mathbf{( B q} / \mathbf{g})\end{array}$ & $\begin{array}{l}\mathbf{R a - 2 2 8} \\
\mathbf{( B q} / \mathbf{g})\end{array}$ & $\begin{array}{l}\mathbf{P b}-210 \\
\mathbf{( B q} / \mathbf{g})\end{array}$ & $\begin{array}{l}\text { Waste Volume } \\
\mathbf{( m}^{3} \mathbf{)}\end{array}$ \\
\hline Battery bund & 6.6 & 0.117 & 6.8 & 3,690 \\
El Sherana village & 0.27 & 0.050 & 0.42 & 1,320 \\
South Alligator village & 2.4 & 0.085 & 2.9 & 1,910 \\
Rockhole tailings residues & 1.9 & 0.081 & 2.18 & 4,500 \\
Weighbridge & 3.6 & 0.022 & 3.1 & 1,980 \\
\hline Containment waste average & 2.7 & 0.080 & 2.9 & 13,400 \\
\hline
\end{tabular}




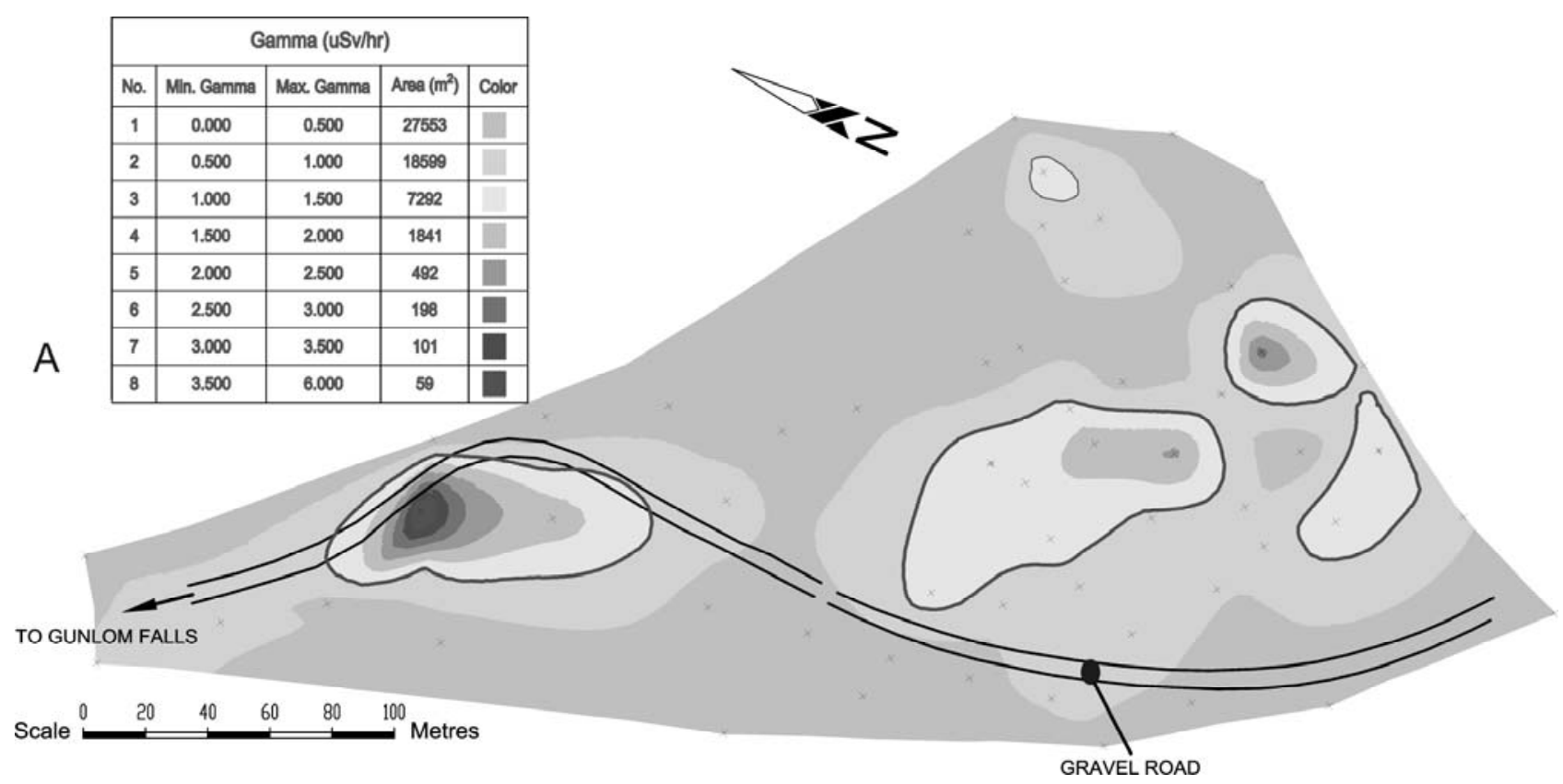

Figure 2 Surface gamma contours at the Rockhole tailings reservoirs. Solid lines show the extent of remediation at the site. Remedial depth is variable but does not extend deeper than $0.5 \mathrm{~m}$

\subsubsection{Containment source term}

Contaminant transport modelling required a source term, or average concentration for the containment. This value was obtained by determining an average volume for each containment, applying a weighting factor to the samples, obtained by using the volume contribution from the sites, then mixing and equilibrating the predicted pore-water concentrations in Phreeqc. The contaminant transport modelling considered the species uranium at $0.13 \mathrm{mg} / \mathrm{L}\left(\mathrm{U}^{+6}\right)$, radium at $72.7 \mathrm{~Bq} / 1\left({ }^{226} \mathrm{Ra}^{+2}\right)$ and chloride as a conservative tracer at $77.5 \mathrm{mg} / 1$ $\left(\mathrm{Cl}^{-}\right)$. Other elements determined to be slightly higher than ANZECC livestock and aquatic guidelines were aluminium and iron, however these were not considered in the source terms as: they are expected to precipitate from leacheate on mixing with groundwaters at the airstrip as supported by Phreeqc modelling; the concentrations were only slightly higher than natural ground water concentration of these elements in the area; and the background concentration of these elements in the airstrip groundwater and pore waters are also higher than the ANZECC guidelines.

\subsection{Containment site materials characterisation}

The containment site materials were identified as a saprolitic soil (chemically weathered rock) of weathered basalt or basaltic andesite. The extent of weathering decreases with depth and it becomes possible to identify the original rock structure, which has extensive staining along joints. There are two distinct levels of weathering present and the relative proportion of hematite and goethite iron- and aluminium-oxides provide a visual method of identifying the two materials. The upper reddish saprolite extends to a depth of $1.5-2.5 \mathrm{~m}$ and the lower yellowish saprolite extends to the bedrock, ranging from 12-20 m depth. The water table beneath the containment facility fluctuates from 12-16 m below ground, from wet to dry season, and is not affected by rainfall and storm events. The saturated hydraulic conductivity of the soils were measured by slug and pump tests on several piezometers at site, completed to the saprolite/weathered bedrock interface, and ranged from $1 \times 10^{-5}$ to $1 \times 10^{-8} \mathrm{~m} / \mathrm{s}$.

A walk-over radiological survey at site gave background (non-contaminated) levels, similar to other nonmining affected areas of the South Alligator River Valley. Piezometer radiochemical analyses showed below detection limit levels of radionuclides within the groundwaters. 


\subsubsection{Geotechnical properties}

Key results from the testing programme showed that the containment site saprolites (clays) have some residual structure remaining. The clays were inorganic and of high plasticity and are non-dispersive. Compaction field trials were conducted to support laboratory testing and to ensure the residual structure of the clays could be removed by reworking the materials to construct an adequate CCL for the cover and base of the containment. The compaction trials allowed several different CCL scenarios to be field-trialled, and allowed construction specifications to be outlined, including the target moisture content, density, and layer thicknesses. Compaction trial results showed that reworking the clays prior to compaction allowed all residual structure to be broken down, achieving very consistent particle size distributions. The average saturated hydraulic conductivity achieved through compaction was $2.1 \times 10^{-10} \mathrm{~m} / \mathrm{s}$, determined by triaxial permeability testing on intact samples obtained from the trial area. Field moisture and density results, laboratory compaction testing (standard and modified), and the triaxial permeability testing indicated that the optimal conditions for compaction of the CCL were $18-22 \%$ moisture and $1.75-1.85 \mathrm{t} / \mathrm{m}^{3}$. Compaction efficiency evaluated on a 16-22\% slope and results showed that compaction efficiency was not compromised over that achieved on the horizontal surface.

\subsubsection{Geochemistry}

Eight solids samples were taken from the El Sherana airstrip test pits. In addition, five water samples were collected from piezometers installed around the airstrip perimeter. Solids and aqueous samples were collected from the airstrip to obtain base line chemistry at the site prior to waste emplacement, and to determine what effects mixing the leachate from the containment wastes would have on the airstrip materials and the effect of mixing the leachate on chemical speciation.

Solids from the El Sherana test pits had an average $\mathrm{pH}$ of 8.6 and slightly reducing conditions $(\mathrm{Eh}=-13 \mathrm{mV})$. Alkalinity was much higher than the waste materials with average bicarbonate $\left(\mathrm{HCO}_{3}{ }^{-}\right)$ concentrations of $125 \mathrm{mg} / \mathrm{L}$ and relatively low sulphate concentrations $\left(\mathrm{SO}_{4}{ }^{-2}\right)$ of $34 \mathrm{mg} / \mathrm{L}$. Radionuclides were not detected above analytical limits. Geochemical speciation modelling of the aqueous samples was used to determine the baseline geochemical conditions in the boreholes at the proposed containment facility, and further, to determine stability of the waste materials in contact with natural groundwater conditions at this site. The water at the El Sherana airstrip is calcium/magnesium - bicarbonate dominated, which is typical of clay-rich groundwater environments.

\subsubsection{Containment leacheate - groundwater chemistry mixing reactions}

The predicted pore-water chemistry from the containment was mixed with predicted pore-water and groundwater chemistry from the El Sherana airstrip. This was done to determine what the result this mixing would have on speciation if leachate from the containment were to migrate into the surrounding soils. The resulting pore water-waste mixtures are predicted to have a $\mathrm{pH}$ of 8.25 and be slightly oxidising. The $\mathrm{pH}$ of the groundwater-waste mixture is 7.1 and oxidising with an Eh of $250 \mathrm{mV}$. Solution chemistry is very similar to that of the existing pore-water chemistry at the airstrip due to considerable dilution of the potential waste leacheate.

An increase in the alkalinity and $\mathrm{pH}$ of the waste materials by mixing into the airstrip pore-waters results in uranium speciation being dominated by uranyl-carbonate species $\left(\mathrm{UO}_{2}\left(\mathrm{CO}_{3}\right)_{2}{ }^{-2}, \mathrm{UO}_{2}\left(\mathrm{CO}_{3}\right)_{3}{ }^{-4}\right)$. These species are highly soluble and potentially mobile within the groundwater environment. Aluminium speciation is similar to that discussed previously for speciation of the containment wastes and no significant change in chemistry with regards to aluminium speciation is present. Aluminium precipitation as aluminosilicate (clay minerals) was predicted within the mixtures. Iron is predicted to be strictly present as $\mathrm{Fe}(\mathrm{III})$ in the mixtures and speciation is predominantly as $\mathrm{Fe}(\mathrm{OH})_{3}$ and $\mathrm{Fe}(\mathrm{OH})_{2}{ }^{+}$. Precipitation of iron is likely as minerals such as hematite, magnetite, goethite and $\mathrm{Fe}(\mathrm{OH})_{3}$ are strongly oversaturated in solution.

Radium speciation within the mixtures is predominated by free $\mathrm{Ra}^{+2}$ and minor $\mathrm{RaSO}_{4}$. Due to the very low concentrations of radium, the saturation indices of radium minerals are highly undersaturated; with no primary radium precipitation predicted to occur. The co-precipitation of radium is readily possible but not quantifiable. Solid-solutions such as $(\mathrm{Ba}, \mathrm{Ra}) \mathrm{SO}_{4}$ and (metal, Ra) $\mathrm{CO}_{3}$ have been reported in waters where the 
concentrations of dissolved sulphate and carbonate are sufficient, as is the case in the groundwaters at this site (Langmuir and Riese, 1985).

\section{$4 \quad$ Climate conditions}

Climatic conditions are critical to assess containment and waste disposal methodology and design. Meteorological data was collated, including daily maximum and minimum air temperature, daily maximum and minimum relative humidity, daily rainfall, and average daily wind speed. Data were obtained from a number of Bureau of Meteorology (BOM) climate stations within the region and a 100 year climate database was constructed for regional groundwater, cover net percolation, and erosion modelling. Table 3 summarises the average climate parameters from the constructed 100 year climate database representative of the Kakadu site. The average annual rainfall is $1,382 \mathrm{~mm} / \mathrm{yr}$, while the average annual potential evaporation (PE) is approximately $2,218 \mathrm{~mm} / \mathrm{yr}$. The annual values indicate that the site is semi-arid. However, during the wet season there are significant periods where rainfall is greater than PE.

Table 3 Summary of the average climate parameters for a 100 year climate database

\begin{tabular}{ll}
\hline Mean/median annual rainfall & $1,382 \mathrm{~mm} / 1,369 \mathrm{~mm}$ \\
Max./min. rainfall (year) & $2,162 \mathrm{~mm}(1974) / 868 \mathrm{~mm}(1952)$ \\
Average daily max./min. temperature & $34^{\circ} \mathrm{C} / 22^{\circ} \mathrm{C}$ \\
Average daily max./min. relative humidity & $68 \% / 44 \%$ \\
Average daily wind speed & $2.3 \mathrm{~m} / \mathrm{s}$ \\
Average annual PE & $2,218 \mathrm{~mm}$ \\
\hline
\end{tabular}

\section{Containment design}

A number of containment designs were examined in light of materials availability on-site, modelling results, and aesthetics. The final preferred containment design will limit ingress of net percolation of water into the waste from the surface as a primary containment system and to limit egress of solutes from the base of the containment as a secondary containment system. The primary containment system within the design (the cover) incorporates $0.5 \mathrm{~m} \mathrm{CCL}$ overlain by minimum of $2 \mathrm{~m}$ growth medium. On top of limiting the egress of solutes downwards towards the water table, there is a risk of exposure to radioactive sources in the waste at the surface of the containment. The method of containment and attenuation of radioactivity is through the thickness of the cover and growth medium layers overlaying the containment. Radiation exposure is not critical in this containment; while the wastes contain radionuclides, the overall activity of the waste is low enough that a simple cover system is suitable for containment and attenuation. The containment was situated over the El Sherana airstrip. The site chosen has the deepest groundwater table in the area, a preferred soil profile including low hydraulic conductivity and minimal impact on the surrounding forest as the area has been cleared of large vegetation already.

The containment is a rectangular excavation which tapers from the top, getting narrower with depth, an elongated, inverted, truncated pyramid. The excavation will have a $500 \mathrm{~mm}$ thick CCL along the base and sides. This lower CCL is designed to be a secondary containment for wastes and will limit the egress of seepage at the base of the containment. This will also limit the seepage of water entering the containment from the sides, although this is unlikely given the hydrogeologic setting of the facility and the site. A perspective view rendering of the final containment is shown in Figure 3.

The cover system is the key component of the facility's design. The primary purpose of placing a cover system on the containment is to minimise impacts to the receiving environments to acceptable levels following completion of the facility. This is achieved through control of net percolation and maintenance of landform stability, both of which ensure the radiologically contaminated material within the containment do not migrate and result in adverse impacts to the receiving environment. Additionally, the cover system will provide a growth medium for establishing a sustainable vegetation cover, which is important for aesthetics, reduced soil erosion and reduced net percolation. 
Various scenarios were examined to obtain the best case containment design. This included erosion modelling of the surface landform using SIBERIA, net percolation modelling through the cover using VADODE/W (Krahn, 2007), and seepage modelling at the base of the containment and regional groundwater flow and transport modelling using FEFLOW (Diersch, 2009). The source terms for contaminant transport modelling were input at steady-state concentrations using FEFLOW.

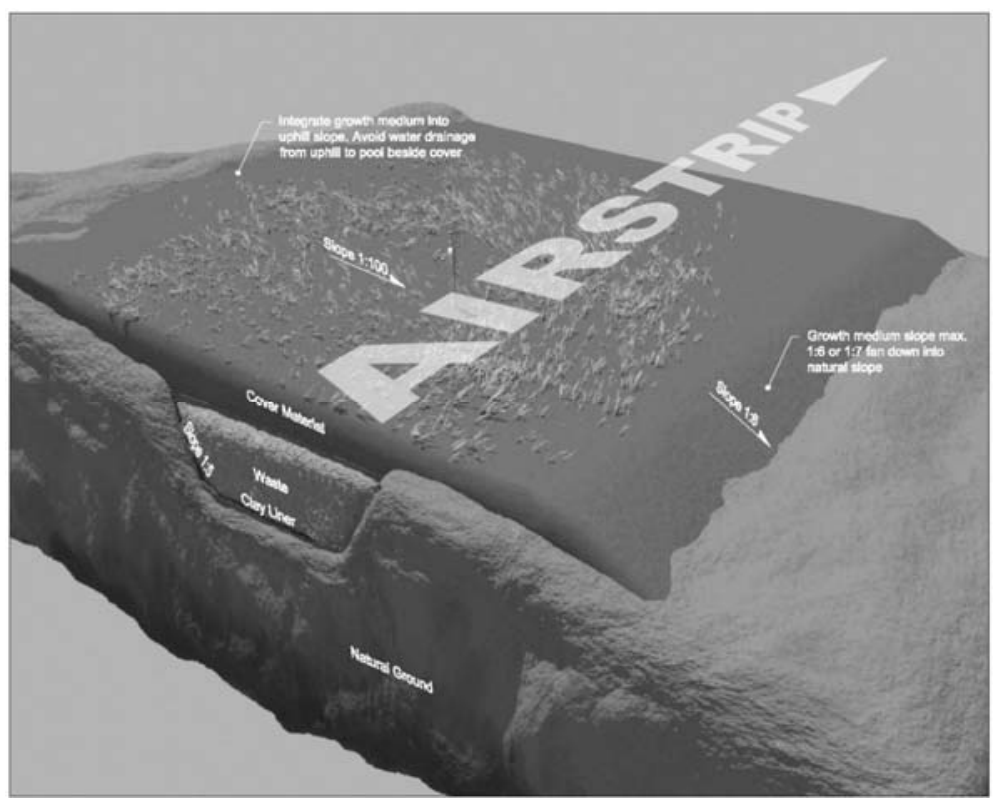

Figure 3 Visualisation of a perspective view of the containment design

\subsection{Cover system design}

The preferred cover system alternative for the El Sherana airstrip was not based solely on the performance of the cover system predicted using the soil-atmosphere model. Factors such as the effect net percolation rates have on the solute flux from the base of the containment, surface erosion, vegetation sustainability, compacted barrier integrity, and cover construction costs were also considered in the selection of the preferred cover alternative. For example, while a thinner growth medium may result in lower net percolation rates, this thinner layer also substantially increases the potential for wet/dry cycling of the underlying compacted layer. Compacted clay covers have the potential to dry and crack in semi-arid climates. The effective hydraulic conductivity of the cover system will increase as water bypasses the soil matrix and flows through shrinkage cracks (Bronswijk, 1991), which will ultimately lead to higher net percolation rates. An inadequate thickness of growth medium is one of the most common reasons for failure of a cover system to sustain design performance criteria.

A 30 year climate database from BOM was used to compare the performance of four cover system alternatives. The cover materials available for use at the airstrip consist of local soil (clay) materials that are available in sufficient quantity to cover and contain the waste material, as outlined in an earlier section. The cover alternatives examined using soil-atmosphere and seepage modelling includes four scenarios presented in Table 4. 
Table 4 Cover scenarios for containment design

\begin{tabular}{ll}
\hline Scenario & Design Features \\
\hline Cover \#1 & $2.0 \mathrm{~m}$ non-compacted growth medium, \\
(base case) & $0.5 \mathrm{~m}$ compacted barrier. \\
Cover \#2 & $1.5 \mathrm{~m}$ surface non-compacted growth medium, \\
& $0.5 \mathrm{~m}$ compacted barrier. \\
Cover \#3 & $1.0 \mathrm{~m}$ surface non-compacted growth medium, \\
& $0.5 \mathrm{~m}$ compacted barrier. \\
Cover \#4 & $2.0 \mathrm{~m}$ surface non-compacted growth medium, \\
& geosynthetic clay liner (GCL), \\
& $0.5 \mathrm{~m}$ compacted barrier. \\
\hline
\end{tabular}

\subsubsection{Predicted net percolation cover scenarios}

The annual net percolation for the 30 year simulation of the base case Cover $\# 1$ was $78 \mathrm{~mm}$, or $5 \%$ of the average annual rainfall. The average actual evapotranspiration (AET) was $946 \mathrm{~mm}$ during the simulation, which is $64 \%$ of the average annual precipitation. The AET values can be further broken down to $443 \mathrm{~mm}$ of actual evaporation and $502 \mathrm{~mm}$ of actual transpiration. On average, $457 \mathrm{~mm} \mathrm{(31 \% )} \mathrm{of} \mathrm{the} \mathrm{wet} \mathrm{season} \mathrm{rainfall}$ produced runoff during the simulation. Predicted net percolation rates are similar for the three alternatives modelled, although somewhat lower as the growth medium thickness decreases. Net percolation rates were $78 \mathrm{~mm} \mathrm{(5 \% )} \mathrm{for} \mathrm{Cover} \mathrm{\# 1,} \mathrm{compared} \mathrm{to} 71 \mathrm{~mm} \mathrm{(5 \% )}$ and $61 \mathrm{~mm} \mathrm{(4 \% )} \mathrm{for} \mathrm{Covers} \mathrm{\# 2} \mathrm{and} \mathrm{\# 3,} \mathrm{respectively.}$ Cover \#3 with the $1 \mathrm{~m}$ growth medium was the first to saturate during the wet season due its reduced storage capacity in comparison to the other cover systems. Runoff was initiated as there was no capacity for the growth medium to store the wet season rainfall, leading to higher average annual runoff. In addition, the thinner growth medium resulted in lower flow gradients through the compacted barrier layer during saturated periods because the hydraulic head was not as high as compared to when the thicker growth medium layers were saturated. The performance of Cover $\# 4$ is similar to the other cover alternatives; during the wet season the growth medium above the low permeability GCL becomes saturated. The low saturated hydraulic conductivity of the GCL substantially reduces net percolation rates during the wet season, leading to higher runoff and AET rates.

From 30 year simulations it was determined that the base case (Cover \#1) was the preferred scenario. This was then evaluated over a 100 year period to provide a more comprehensive prediction of cover system performance. Net percolation predicted for the 1908-1977 period was $68 \mathrm{~mm}$, or 5\% of the average annual rainfall at the site. This performance is the same as predicted during the 1978-2007 period. For the full 100 year simulation, runoff was $30 \%$, AET was $65 \%$, and net percolation was $5 \%$ of the average annual $1,380 \mathrm{~mm}$ of rainfall. Table 5 summarises the water balance parameters for the base case cover for the 100 year continuous simulations. 
Table 5 Water balance parameters predicted for base case cover system (Cover \#1) over varying climate periods

\begin{tabular}{llll}
\hline Parameter & $\begin{array}{l}\text { 1908-1977 } \\
\text { (70 year) }\end{array}$ & $\begin{array}{l}\text { 1978-2007 } \\
\text { (30 year) }\end{array}$ & $\begin{array}{l}\text { 1908-2007 } \\
\text { (100 year) }\end{array}$ \\
\hline Rainfall & $1,340 \mathrm{~mm}$ & $1,483 \mathrm{~mm}$ & $1,382 \mathrm{~mm}$ \\
Potential evaporation & $2,183 \mathrm{~mm}$ & $2,282 \mathrm{~mm}$ & $2,218 \mathrm{~mm}$ \\
Runoff & $391 \mathrm{~mm}(29 \%)$ & $457 \mathrm{~mm}(31 \%)$ & $411 \mathrm{~mm}(30 \%)$ \\
Actual evaporation & $412 \mathrm{~mm} \mathrm{(31 \% )}$ & $443 \mathrm{~mm}(30 \%)$ & $421 \mathrm{~mm}(30 \%)$ \\
Actual transpiration & $472 \mathrm{~mm}(35 \%)$ & $502 \mathrm{~mm}(34 \%)$ & $481 \mathrm{~mm}(35 \%)$ \\
Actual evapotranspiration & $884 \mathrm{~mm}(66 \%)$ & $945 \mathrm{~mm}(64 \%)$ & $902 \mathrm{~mm}(65 \%)$ \\
Net percolation & $68 \mathrm{~mm}(5 \%)$ & $78 \mathrm{~mm}(5 \%)$ & $71 \mathrm{~mm}(5 \%)$ \\
\hline
\end{tabular}

\subsubsection{Radon emanation at cover system surface}

The soil-atmosphere modelling using VADOSE/W was also used to predict radon emanation rates for the cover system alternatives. It was assumed that diffusion would be the primary transport mechanism for the upward movement of radon gas. A constant radiation source of $10.2 \mathrm{~Bq} / \mathrm{s} \cdot \mathrm{m}^{2}$ was placed at the top of the waste profile and the resulting radiation was evaluated at the surface by the model. The average daily radon emitted from the surface of Cover \#1 was reduced by $98.5 \%$ from that produced within the containment.

\subsection{Containment seepage and solute concentration predictions}

The overall objective of the seepage analysis was to evaluate the effect of potential (and alternative) cover system design scenarios on groundwater and surface water quality. The aim was to minimise infiltration rates and, as a result, solute generation rates. In addition, an understanding of the effect of the hydraulic characteristics of the compacted liner on seepage rates was essential to ensure the subsurface containment does not saturate. Figure 4 shows the pressure head distribution in the containment for the base case cover $(5 \%)$ at steady state seepage rates. The pressure heads within the containment for the base case cover system design remain negative (unsaturated) for the base case liner hydraulic conductivity $\left(1 \times 10^{-7} \mathrm{~cm} / \mathrm{s}\right)$. Transient seepage and solute transport analysis was conducted to assess the time to reach constant solute concentrations at the base of the containment liner. Simulations were conducted until the solute in question (radium, uranium or chloride) reached constant concentration or for 500 years (whichever came first). Radium did not reach constant concentration after 500 years when the concentration was $16.5 \mathrm{~Bq} / \mathrm{l}$. Uranium reached constant concentration at 350 years. Chloride measured at the base of the containment liner was $72 \mathrm{mg} / \mathrm{l}$ and reached constant concentration after six years. As chloride does not react with the solid phase this gives the shortest possible transport times. The ability of the compacted clay liner to absorb uranium and radium accounts for the time to reach a constant concentration compared to chloride. 


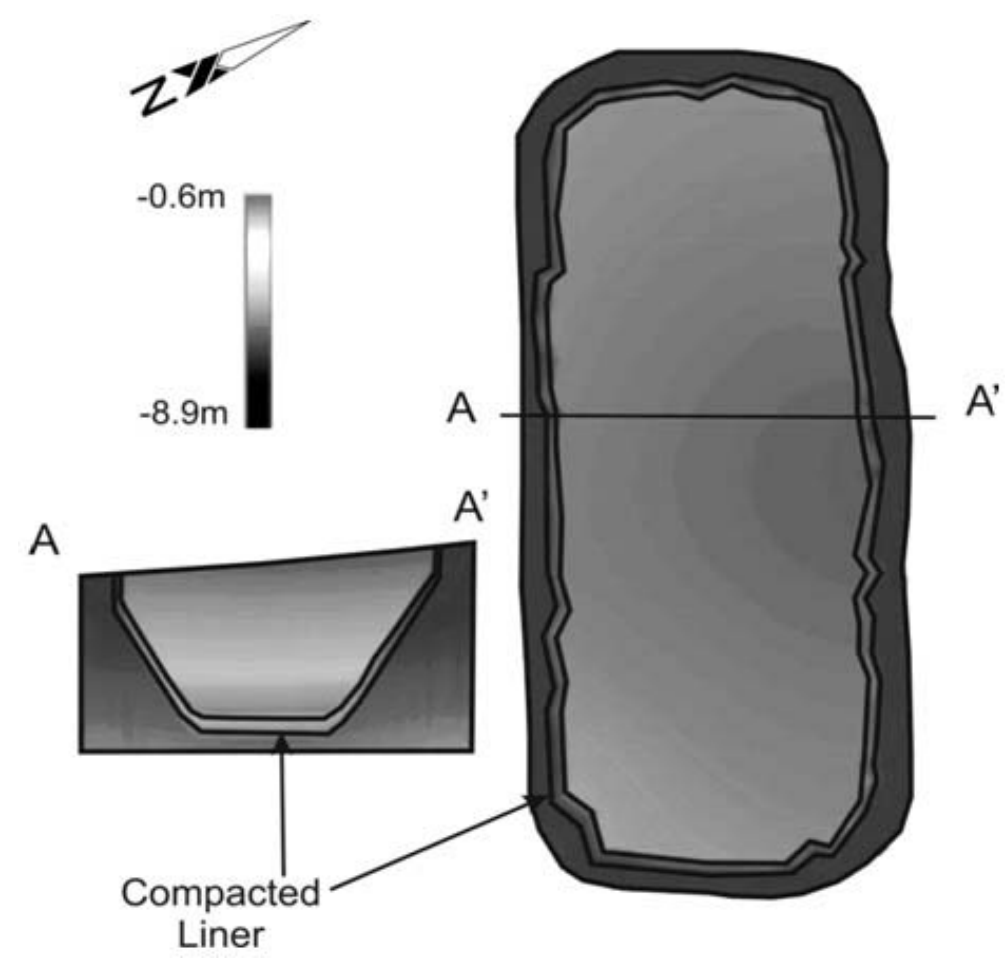

Figure 4 Distribution of predicted pressure heads in and around the containment during the wet season in 2000

\subsection{Regional groundwater and mass transport modelling}

Potential impacts of the predicted seepage rates and solutes concentrations on downstream receptors were assessed through regional groundwater flow and mass transport modelling. Regional groundwater flow mimics the surrounding topography with recharge occurring at the ridges in the vicinity of the El Sherana airstrip resulting in a flow direction approximately northeast to southwest under the proposed containment location. The surficial clays and underlying bedrock were assumed to be hydraulically connected to the South Alligator River, which is the potential downstream receptor of solutes. The groundwater flow assessment was found to be important primarily to assess the effect of radium and uranium leaching from the containment. The mass transport model was simulated for 300 years during which time no detectable levels of radium were predicted at the South Alligator River.

Radium concentrations predicted after 300 years of simulation time below and downstream from the containment were negligible, with a maximum concentration measured at the surface of the water table $(5 \mathrm{~m}$ below containment base) of $8.4 \times 10^{-7} \mathrm{~Bq} / 1$, substantially below the ANZECC standard for livestock of $5 \mathrm{~Bq} / \mathrm{l}$. This prediction shows the El Sherana clay will sufficiently attenuate the radium measured in the waste material. Maximum predicted uranium concentrations $\left(<9 \times 10^{-6} \mathrm{mg} / \mathrm{l}\right)$ below and downstream from the containment were well below the ANZECC standard for livestock drinking water of $0.2 \mathrm{mg} / \mathrm{l}$. Uranium migration was predicted to be within five metres of the containment after 300 years of simulations. The El Sherana clay was determined to sufficiently attenuate the uranium migrating from the waste material.

\section{Containment facility monitoring}

A surveillance and monitoring programme is the key element in ensuring that the containment facility provides the required level of containment, isolation and protection. The monitoring and surveillance programme is designed to demonstrate the containment design objectives are being met over time. The containment is designed so that there will not be any significant migration of contaminated material from the disposal facility. The surveillance and monitoring programme is designed to: provide direct evidence of the measureable presence or otherwise non-detectability of radionuclides and radiation in the environment attributable to the disposal facility; provide support for the assumptions, choice of parameters, and findings 
of the design of the containment; and provide information to support demonstration of compliance with design objectives.

The containment has been designed such that the liner is a secondary containment system with the cover being used as the primary means of controlling leachate generated from the contained waste. As shown by the seepage and groundwater models, the transport of possibly contaminated waters from the containment facility may not be detectable in groundwater for a long time. In this situation monitoring of the vadose zone provides a possibility for earlier detection of any deterioration of the disposal facility's integrity and is included as part of the programme (IAEA, 2004). Monitoring and instrumentation of the containment focuses on several variables. These are erosion and landform stability, vegetation, cover system water balance monitoring and leacheate monitoring.

Key cover system water balance components will be monitored, including runoff, rainfall, net radiation (for calculating potential evaporation), in situ cover system moisture/suction, and net percolation. Increases in the concentration of solutes in the vadose zone pore-water can be caused by infiltration of surface water through the containment cover. The acceptability in terms of net percolation through the cover system was determined through modelling. This will be the basis on which monitoring will take place within and below the growth medium and compacted clay cover. Monitoring is completed at three sites, all which include identical instrumentation, allowing a level of redundancy. This will ensure that if instrumentation malfunctions at any depth in the containment, measurements are still occurring at another site. In addition the triplicate stations provide a better idea of performance throughout the containment should any heterogeneity exist.

\subsection{Cover instrumentation}

The containment monitoring includes provision for cover system water balance instrumentation. This consists of volumetric water content sensors and in situ matric suction sensors. Changes in cover system moisture storage will be measured using soil matric suction sensors installed vertically into the cover and underlying waste material at strategic locations. The containment also includes gas sampling ports at various depths through the cover to monitor radon gas egress from the waste materials.

Surface runoff is monitored to ensure that a representative surface water balance can be developed for the containment. Two runoff systems consisting of a known runoff area and a lined drainage channel leading to a large-scale tipping bucket system (Landloch Pty Ltd) are installed to determine the amount of erosion and runoff from the cover surface. Large tipping buckets are capable of measuring extreme runoff events on a large-scale area making them ideal on a full-scale cover over the containment. Further to this, the degree of erosion will be measured by manual surveys on distinct areas on the side slopes and the top of the cover. Initial post-construction surface conditions with respect to rills, gullies and troughs will be recorded until a stable landform has evolved. The subsidence of the waste materials may affect the integrity of the compacted clay layer in the cover system. To monitor the subsidence survey markers are installed through the length of the containment on the surface of the cover and will be periodically surveyed as part of the monitoring programme.

\subsection{Waste and containment base instrumentation}

Volumetric water content sensors and in situ matric suction sensors (Campbell Scientific Pty Ltd) are continued through the waste, compacted clay liner and underlying geologic media. Net percolation is measured by three Gee Passive Capillary Lysimeters (Decagon Devices, Inc) at each monitoring station. These lysimeters collect a volume of water which can be removed though a flexible hose, which extends to the surface. Sampling is performed using a peristaltic pump. Each lysimeter contains a moisture content probe inside and outside the collection area to ensure that conditions at which the lysimeters were placed are reflective of in situ conditions.

Two vibrating wire piezometers (Geotechnical Systems Australia) are installed at each monitoring location, directly above and below the liner to monitor the development of any positive pore-water pressures within the containment. This supports information provided by lysimeters and moisture/matric suction instrumentation. 
Water level and solute concentration are measured in piezometers. Additional piezometers were installed to supplement the existing ones to monitor both the groundwater level with respect to the containment and to determine if solute migration is occurring from the containment. The additional piezometers were installed with the aid of regional groundwater modelling results and are placed strategically to intercept potential leacheate.

\section{$7 \quad$ Appropriateness of cover design in light of the Rum Jungle experience}

The El Sherana airstrip cover needs to be appropriate in light of issues that arose from flaws in the Rum Jungle cover design. This section summarises the overall cover design and remediation plans by comparison to the aspects of the Rum Jungle rehabilitation that failed. The Rum Jungle Mine is close to the containment site (180 km northwest) therefore climatic conditions are similar, and both covers were designed to be store and release covers utilising a compacted clay layer. Taylor et al. (2003) studied the failure of the waste rock dump covers over White's Heap placed in 1984-1985 at Rum Jungle. The covers were intended to reduce the water infiltration to less than five per cent of incident rainfall through both runoff and store and release methods. The conclusion of this joint study was that the design of the cover was appropriate, however small and localised area of the cover failed due to poor construction and material QA/QC. Additionally, it appears that there was a shortage of appropriate materials for each of the three cover materials, the low permeability compacted clay layer, the store and release layer and the upper erosion resistant layer. The cover system did not contain a capillary break layer resulting in capillary rise which acidified and modified the compacted clay layer over the waste dump. Aside from as-built construction issues, the cover profile at Rum Jungle was specified by ANSTO to have (from waste upwards); 150-225 mm compacted layer; 150-250 $\mathrm{mm}$ moisture storage layer; and 0-150 $\mathrm{mm}$ erosion resistant gravel and sand (Taylor et al., 2003)

It is interpreted by Taylor et al. (2003) that the cover design was sufficient to limit net infiltration into the waste rock. This is, however, not the case as a minimum specification of $300 \mathrm{~mm}$ growth medium (moisture storage and erosion layer) for the climate at Rum Jungle will inevitably fail as there is not enough moisture storage in the growth medium to prevent desiccation of the underlying compacted layer during dry climatic conditions, and an atmospheric demand for moisture exists.

An increased permeability was found in the Rum Jungle cover, attributed in the report to burrowing (termites), root penetration, and shrinkage and desiccation cracks formed in the compacted clay layer. The effects of root penetration and burrowing were likely present. This should, however, not have been sufficient to increase the permeability of the cover to the extent reported. It is likely that the thin growth medium was not sufficient to inhibit wet/dry cycling of the compacted clay layer, which subsequently degraded this layer. Wet/dry cycling will impact moisture retention and hydraulic conductivity of a compacted layer designed to be a hydraulic barrier. Compacted clay covers have the potential to dry and crack in semi-arid climates and the effective hydraulic conductivity of the cover system will increase as water bypasses the soil matrix and flows through shrinkage cracks (Bronswijk, 1991).

In addition, the barrel-type lysimeters installed at Rum Jungle are highly maintenance intensive and may have resulted in an underestimation of the net percolation through the cover system. The barrel-type lysimeters are not underdrained and need continual monitoring and pumping to maintain optimal performance. As percolating water collects in the lysimeter, the perched water table within the lysimeter increases in height, thereby decreasing the suction at the cover system/waste material interface above the lysimeter. This increases the propensity for bypass flow around the lysimeter because the suction conditions outside of the lysimeter are greater than inside the lysimeter, effectively pulling, or wicking, water around the lysimeter (O'Kane and Barbour, 2003). Infrequent testing of the lysimeters results in a much lower net percolation predicted than actually occurs. A more detailed monitoring programme initiated when it was apparent that the cover was not performing would have shown an increase in net percolation with time.

All of the issues that arose from the Rum Jungle example are predicted to be of no concern in the design for the containment at El Sherana airstrip. The containment design at the El Sherana airstrip addresses the longterm physical, chemical and biological processes that can potentially adversely impact on containment performance as shown in INAP (2003). The differences in the current containment to the minor failures of the Rum Jungle example are addressed systematically on the following page. 
The growth medium utilised at the El Sherana containment is nearly an order of magnitude thicker than that at Rum Jungle (minimum of $2.5 \mathrm{~m}$ versus $0.3 \mathrm{~m}$ ). This is sufficient to provide proper moisture store and release performance. Soil-atmosphere modelling predicted that the compacted clay layer will remain sufficiently saturated to retain its integrity. For example, the time period from 1925-29 represents the driest consecutive five year period from the 100 year climate database constructed, and during this time the minimum degree of saturation in the compacted layer is predicted to range from 81-82 per cent. This is sufficient to retain structure without desiccation and drying of the layer, and also sufficient to remain an effective diffusion barrier for gas, notably for this site, radon (Mbonimpa et al., 2003).

The area for the El Sherana containment is relatively small and, as such, QA/QC of each of the engineered barriers and layers can be closely monitored during construction. Engineering technicians will be on-site at all times performing control checks on the construction. If a layer is not placed to engineering specification, it will be pulled up and re-laid.

The compacted clay cover at White's heap reportedly was not constructed from the specified materials. Compacted lateritic clays were specified (as in the El Sherana containment), however, the actual materials observed were gravelly and sandy clays, with two to four orders of magnitude more permeable than design (Taylor et al., 2003). At the El Sherana airstrip, full-scale compaction trials were conducted using actual site materials (of which sufficient material exists). This included in situ and laboratory testing to verify that the materials at site were appropriate for construction; therefore these issues will not occur.

A lack of a capillary break material was attributed to another failure at Rum Jungle, as the compacted clay materials were directly overlain on coarse waste rock. This is not an issue at El Sherana, as the materials transfer will be staged so that the coarsest materials (consisting of a minimal amount of waste rock) are placed in the centre of the containment, surrounded by fine grained materials. This serves two purposes: to ensure that a capillary break is not required under the compacted clay layer; and that additional hydraulic conductivity barrier for contaminant transport is seen on top of that predicted through the compacted clay layer and natural clays surrounding the containment.

Measurement of net percolation through the cover and subsequently at the base of the containment is measured using a variety of sensors and monitoring equipment. The instrumentation provides a measure of redundancy that is critical in such an installation and all instrumentation is automated. Aside from collecting net percolation from the lysimeters and water samples from piezometers at site, lysimeter and other equipment performance will not be affected by lack of maintenance.

\section{Acknowledgements}

The authors would like to thank the area's traditional Aboriginal owners, members of the Werenbun Aboriginal Corporation for their full support and cooperation in the works. Bruce Ryan and Andreas Bollhöfer from Environmental Research Institute of the Supervising Scientist (ERISS) provided assistance on the project both in the field and for the generous provision of background information. The authors also thank the reviewing committee for their suggestions of additions to the manuscript, notably the inclusion of a comparison to Rum Jungle and a discussion regarding the consultation with the traditional owners.

\section{References}

Australian and New Zealand Environment and Conservation Council (ANZECC) (2000) Australian and New Zealand guidelines for fresh and marine water quality, Australian and New Zealand Environment and Conservation Council and Agriculture and Resource Management Council of Australia and New Zealand. Canberra, Australia.

Australian Radiation Protection and Nuclear Safety Authority (ARPANSA) (2002) Recommendations for limiting exposure to ionizing radiation, Australian Radiation Protection and Nuclear Safety Authority Radiation Protection Series Publication, No. 1, 62 p.

Bronswijk, J.J.B. (1991) Drying, cracking, and subsidence of a clay soil in a lysimeter, Soil Science, Vol. 152, No. 2, pp. 92-99.

Diersch, H-J.G. (2009) FEFLOW 5.4, finite element and subsurface flow \& transport simulation system - Users manual, DHI-WASY GmbH, 201 p.

EcOz Environmental Services (2007) Preliminary environmental assessment of the above ground impacts of a proposed containment facility El Sherana airstrip, Gunlom Land Trust, Kakadu National Park, Report for Parks Australia North, January 2007. 
Earth Water Life Sciences and Fawcett Mine Rehabilitation Services (EWL and FMRS) (2003) Desk top review: Potential containment sites for radiologically contaminated material, Gunlom Land Trust, Kakadu, Report for Parks Australia, May 2003.

Earth Water Life Sciences (EWL) (2007) Groundwater level monitoring and permeability tests - Candidate containment sites (Gunlom radiological materials), Report for Parks Australia, August 2006.

Fawcett Mine Rehabilitation Services (FMRS) (2007) Installation of monitoring bores at El Sherana airstrip, 14-15 December 2006, Supervisor's Report for Parks Australia, January 2007.

Hummel, W., Berner, U., Curti, E., Pearson, F.J. and Thoenen, T. (2002) Nagra/PSI chemical thermodynamic data base 01/01, Universal Publishers, Parkland USA, 565 p.

International Atomic Energy Agency (IAEA) (2004) Surveillance and monitoring of near surface disposal facilities for radioactive waste, Vienna, Austria, $81 \mathrm{p}$.

International Network for Acid Prevention (INAP) (2003) Evaluation of the long-term performance of dry cover systems, final report, Prepared by O'Kane Consultants Inc., Report No. 684-02, March 2003.

Johnson, J. (1992) Lawrence Livermore National Laboratory 'thermo.com.V8.R6.230' chemical database, Converted to Phreeqc format by Greg Anderson and David Parkhurst, February 2005.

Krahn, J. (2007) Vadose Zone Modeling with VADOSE/W - An Engineering Methodology, Second Edition, GEOSLOPE International Ltd, May 2007.

Langmuir, D. and Riese, A.C. (1985) The thermodynamic properties of radium, Geochimica et Cosmochimica Acta 49, pp. 1593-1601.

Mbonimpa, M., Aubertin, M., Aachib, M. and Bussière, B. (2003) Diffusion and consumption of oxygen in unsaturated cover materials, Canadian Geotechnical Journal, Vol. 40, pp. 916-932.

National Parks (2007) The Northern Territory of Australia (Gunlom Aboriginal Land Trust) National Park Memorandum of Lease, 14 January 1996.

National Health and Medical Research Council (NHMRC) (2004) National Water Quality Management Strategy, Australian drinking water guidelines 6, Endorsed by NHMRC 10-11 April 2003, Australian Government, 615 p.

O'Kane, M. and Barbour, S.L. (2003) Predicting field performance of lysimeters used to evaluate cover systems for mine waste, In Proceedings of Sixth Annual International Conference on Acid Rock Drainage (ICARD), 12-18 July 2003, Cairns, Australia, Australian Institute of Mining and Metallurgy. pp. 327-339.

Parkhurst, D.L. and Appelo, C.A.J. (1999) User's guide to PHREEQC (Version 2) - A computer program for speciation, batch-reaction, one-dimensional transport, and inverse geochemical calculations, United States Geological Survey, Water-Resources Investigations Report 99-4259, 312 p.

Pfitzner, K. and Martin, P. (2003) Mapping the upper South Alligator River Valley using integrated datasets, Internal Report 444, Supervising Scientist, Darwin, Australia, 31 p.

Press, A.J. and Lawrence, D. (1995) Kakadu National Park: reconciling competing interests, In Kakadu: natural and cultural heritage and management, A.J. Press, D. Lea, A. Webb and A. Graham (eds), Australian National University, North Australia Research Unit, Darwin, Australia pp. 1-14.

Stockton, D., Jones, D., Zimmerman, A., Lewis, G., Fawcett, M., Carter, M. and Corbett, L. (2003) Rehabilitation Plan for abandoned mine sites and associated infrastructure, Gunlom Land Trust, Kakadu, Part A, Draft report for Parks Australia North, April 2003, 80 p.

Taylor, G., Spain, A., Nefiodovas, A., Timms, G., Kuznetsov, V. and Bennett, J. (2003) Determination for the reasons for deterioration of the Rum Jungle waste rock cover, Australian Centre for Mining Environmental Research, Brisbane, Australia, 119 p.

Waggitt, P.W. (2004) Uranium mine rehabilitation: the story of the South Alligator Valley intervention, Journal of Environmental Radioactivity, 76, pp. 51-66.

Waggitt, P.W. (2003) South Alligator Valley abandoned uranium mines - hazard reduction programme: Triennial radiation survey - October 2002, Internal Report 408, Supervising Scientist, Darwin, Australia, 11 pp. 